Review

\title{
Gastric Microenvironment-A Partnership between Innate Immunity and Gastric Microbiota Tricks Helicobacter pylori
}

\author{
Cristina Oana Mărginean ${ }^{1}\left(\mathbb{D}\right.$, Lorena Elena Meliț ${ }^{1, *}$ and Maria Oana Săsăran ${ }^{2}$ \\ 1 Department of Pediatrics I, George Emil Palade University of Medicine, Pharmacy, Science, and Technology of \\ Târgu Mureș, Gheorghe Marinescu Street No. 38, 540136 Târgu Mureș, Romania; marginean.oana@gmail.com \\ 2 Department of Pediatrics III, George Emil Palade University of Medicine, Pharmacy, Science, and Technology \\ of Târgu Mureș, Gheorghe Marinescu Street No. 38, 540136 Târgu Mureș, Romania; oanam93@yahoo.com \\ * Correspondence: lory_chimista89@yahoo.com; Tel.: +40-742-984-744
}

Citation: Mărginean, C.O.; Melit, L.E.; Săsăran, M.O. Gastric

Microenvironment-A Partnership between Innate Immunity and Gastric Microbiota Tricks Helicobacter pylori. J. Clin. Med. 2021, 10, 3258. https://doi.org/10.3390/jcm 10153258

Academic Editor: Marilena Durazzo

Received: 5 July 2021

Accepted: 21 July 2021

Published: 23 July 2021

Publisher's Note: MDPI stays neutral with regard to jurisdictional claims in published maps and institutional affiliations.

Copyright: (c) 2021 by the authors. Licensee MDPI, Basel, Switzerland. This article is an open access article distributed under the terms and conditions of the Creative Commons Attribution (CC BY) license (https:/ / creativecommons.org/licenses/by/ $4.0 /)$.

\begin{abstract}
Helicobacter pylori (H. pylori) carcinogenicity depends on three major factors: bacterial virulence constituents, environmental factors and host's genetic susceptibility. The relationship between microenvironmental factors and H. pylori virulence factors are incontestable. H. pylori infection has a major impact on both gastric and colonic microbiota. The presence of non- $H$. pylori bacteria within the gastric ecosystem is particularly important since they might persistently act as an antigenic stimulus or establish a partnership with $H$. pylori in order to augment the subsequent inflammatory responses. The gastric ecosystem, i.e., microbiota composition in children with $H$. pylori infection is dominated by Streptoccocus, Neisseria, Rothia and Staphylococcus. The impairment of this ecosystem enhances growth and invasion of different pathogenic bacteria, further impairing the balance between the immune system and mucosal barrier. Moreover, altered microbiota due to H. pylori infection is involved in increasing the gastric T regulatory cells response in children. Since gastric homeostasis is defined by the partnership between commensal bacteria and host's immune system, this review is focused on how pathogen recognition through toll-like receptors (TLRs-an essential class of pathogen recognition receptors-PRRs) on the surface of macrophages and dendritic cells impact the immune response in the setting of $H$. pylori infection. Further studies are required for delineate precise role of bacterial community features and of immune system components.
\end{abstract}

Keywords: gastric microbiota; innate immunity; Helicobacter pylori; bacterial community; children

\section{Introduction}

Helicobacter pylori (H. pylori) is probably the most common bacterial infection worldwide. As it is well-known, this infection is particularly important in children since it is usually acquired during childhood and its seroprevalence increases with age. Moreover, if left untreated, $H$. pylori infection results in a chronic inflammation of the gastric mucosa and imminent long-term carcinogenesis. Thus, it was proved that $80 \%$ of all gastric cancers and $5.5 \%$ of all malignancies are related to the injuries produced by this bacterium $[1,2]$. The World Health Organization considered H. pylori as a class I carcinogen since gastric cancers associated to this infection are amongst the first three most common causes of death worldwide [3]. Its carcinogenicity depends on three major factors: bacterial virulence constituents, environmental factors and host's genetic susceptibility [4]. In terms of bacterial virulence, $H$. pylori has developed a wide spectrum of mechanisms in order to survive and escape the host's defense immune responses. Among these mechanisms, we recall the ability to regulate T-cell responses, the inhibition of cathepsin $\mathrm{X}$ or the altered structure of lipopolysaccharides, which are definitely involved in the mediation of resistance against drugs [5]. Therefore, a recent study performed on European individuals revealed that the primary resistance rates against clarithromycin and metronidazole have reached $17.5 \%$ and $34.9 \%$, respectively [6]. Moreover, the same study pointed out that resistant strains to levofloxacin have emerged impairing its effectiveness as rescue therapy [6]. As we already 
mentioned, environmental factors also play a major role in the persistence of this infection, including socio-economic conditions, originating area, dietary habits or certain practices within the household [7-9]. Gastric microenvironment defined mostly by gastric microbiota influences the development of $H$. pylori gastritis and even immune responses [10,11]. Thus, we hypothesize that the complex interrelationship between $H$. pylori, gastric microbiota and innate immune responses shapes the pathophysiology of $H$. pylori-related disorders and the persistence of this infection during adulthood.

\section{New Insights on Pediatric H. pylori Infection}

H. pylori is a well-defined microaerophilic, Gram-negative bacterium that usually colonizes the human gastric mucosa during childhood and it might result in long-life inflammation and subsequent development of a wide spectrum of gastropathies like chronic gastritis, peptic ulcer disease and even certain types of malignant disorders $[12,13]$. Recent epidemiologic studies have reported a decreasing prevalence of pediatric $H$. pylori infection pointing out a significant difference between $25.6 \%$ in 2005 and $12.8 \%$ in 2017 [14]. Nevertheless, wide variations were reported among different populations in terms of prevalence mostly depending on the socio-economic status [7,8,14-20].

The clinical spectrum of this infection in children varies from asymptomatic to lifethreatening conditions, such as peptic ulcer disease [21,22]. Nevertheless, the symptoms in children with $H$. pylori infection remain unspecific including abdominal pain, nausea, vomiting, heartburn [21,23], and thus the most recent recommendation of the European Society for Paediatric Gastroenterology, Hepatology and Nutrition (ESPGHAN) and the North American Society for Paediatric Gastroenterology, Hepatology and Nutrition (NASPGHAN) is to perform the necessary investigation for identifying the underlying cause of the symptoms and not only for assessing the presence of this infection [24]. A wide spectrum of extra-digestive conditions were proven to be associated to this infection, among which cardiovascular diseases, stroke, anemia, idiopathic thrombocytopenic purpura, eczema, rosacea, chronic hives, diabetes, thyroid disease or Alzheimer's disease, which might be explained by the systemic inflammatory status identified even in pediatric patients diagnosed with $H$. pylori-positive gastritis $[7,8]$. Taking into account the severity of these aforementioned conditions and their long-life chronic pattern, the assessment of $H$. pylori related systemic inflammation should be a main goal in patients with this infection. The standard recommendation for diagnosing H. pylori infection implies only symptomatic children [24]. Thus, non-invasive tests are the most commonly used in daily practice in order to establish this diagnosis, but upper digestive endoscopy-based test definitely provide a more complete and accurate diagnosis.

The recent guidelines no longer recommend a 'test and treat strategy' in pediatric patients [24]. The standard therapy involves an association between a proton pump inhibitor and two antibiotics at high doses for 2 weeks [24]. Taking into consideration the differences between different countries in terms of exposure and common use of certain antibiotics, this therapy should be tailored for each population [10]. Thus, Silva et al. proved that tailored therapy associated with proton pump inhibitors in children results in an eradication rate of $97.8 \%$ [25]. In pediatric patients, therapy success is further hindered by poor compliance, inadequate dose or duration, inactivation of antimicrobial agents to low gastric $\mathrm{pH}$ or their inappropriate penetration into the gastric mucosa [10]. Another study that assessed the efficacy of sequential therapy on 40 symptomatic children using amoxicillin and lansoprazole for 5 days, followed by clarithromycin, metronidazole and lansoprazole for another 5 days proved that the eradication rate might reach up to $82.5 \%$ [26]. Potassium-competitive acid blockers, the most recent class of gastric acid suppressor, were assessed in high school students with $H$. pylori infection, in association with amoxicillin and clarithromycin, and the eradication was successful in $85.1 \%$ of the cases [20]. The supplementation of Lactobacillus might be beneficial in the eradication of $H$. pylori infection [27], but the studies on this topic remain controversial [10]. Thus, Eslami et al. pointed out that probiotics supplementation to triple therapy could increase the eradication rate and reduce the antibiotics 
side-effects [28]. Similar findings were encountered in pediatric patients according to a recent meta-analysis performed by Feng et al., who underlined that the effectiveness of triple therapy depends on specific probiotic supplementation [29].

In terms of pathophysiology the reports on children are scarce. Nonetheless, the relationship between microenvironmental factors, $H$. pylori virulence factors and immune activation are incontestable [10]. Specifically, the immune response mediated by toll-like receptors (TLRs) and microRNAs (miRNA) have been shown to play a role in the suppression or promotion of $H$. pylori-related gastropathies [11,30,31]. Thus, miRNA-155 is expressed by a wide-spectrum of immune cells in context of inflammatory response and it acts as an essential regulator of innate immune responses [30]. In pediatric patients, a study performed by Cortes-Marquez et al. concluded that the expression of certain types of miRNA might indicate the severity and the chronicity of the disease pointing out that the overexpression of miRNA-155 and miRNA-146a are associated with the persistence and outcome of $H$. pylori infection [31]. TLRs, which will be further detailed in another section, were also related to the persistence of this infection, playing a crucial role in gastric carcinogenesis [11]. Moreover, H. pylori binding avidity is definitely another sine qua non condition for the severity and persistence of this infection since the strains identified in children with peptic ulcer disease were shown to express a higher binding avidity as compared to those encountered in pediatric patients with non-ulcer dyspeptic symptoms [24]. Aside from the ability of this bacterium to bind and adhere to the gastric mucosa, other virulence factors were reported to be involved in promoting its persistence such as $c a g A$, vacA, babA2, homB and oipA genes [10]. CagA is probably the most studied virulence factor and it is involved particularly in the development of both gastric and extra-digestive manifestations associated to H. pylori infection [32]. Moreover, the genera of H. pylori identified in children with peptic ulcer disease were shown to express a higher binding avidity as compared to those encountered in pediatric patients with non-ulcer dyspeptic symptoms [33]. Therefore, the complex interaction between all these factors related either to H. pylori itself or host-defense mechanisms definitely require further attention in order to delineate their precise role in children.

\section{Innate Immunity and Gastric Microbiota-The 'Yin and Yang' of H. pylori Infection}

Human homeostasis is defined by the proper relationship between microbiota and host's immune responses [34]. The puzzle of gastric microbiota is still far to be elucidated. It is true that gastric microenvironment owns less hospitable living conditions for microorganism such as the proteolytic activity of the gastric juice, low $\mathrm{pH}$, bile acids reflux, the synthesis of nitric oxide from salivary nitrate expressing antimicrobial properties; but still the presence of microorganisms in the gastric juice was identified 150 years before the description of $H$. pylori $[35,36]$ destroying the hypothesis that stomach is a sterile environment. Further studies proved that bacteria are not the single microorganisms living in the stomach, identifying also different classes of fungi from the gastric samples [37]. H. pylori infection has a major impact on both gastric and colonic microbiota and several studies have assessed the interaction between this infection and the diversity of bacteria colonizing the gastrointestinal tract.

\subsection{Gastric Microenvironment among Adults}

Further studies revealed that gastric microbiota is diverse and depends on both host's underlying gastropathy and external factors, such as geographic area. A very recent metaanalysis that assessed 36 studies on this topic pointed out that Prevotella and Streptococcus were the most frequently identified in the gastric samples, followed by Neisseria reported in 25 studies, as well as Veillonella, Haemophilus and Fusobacterium, identified in 24 of these studies [37]. Out of the 266 bacterial genera identified in these 36 studies, the majority were extremely rare or might even be artefacts as a result of bioinformatic processing or technical errors of sequencing [37]. The information regarding gastric microbiota in healthy individuals is limited since most of the studies focused on assessing patients with 
either H. pylori related gastropathies or gastric cancer. Nevertheless, 6 bacterial genera were reported in 88 healthy subjects: Prevotella, Streptococcus, Megasphaerae, Oribacterium, Capnocutophaga and Propionibacterium [37-40]. Another well-documented fact is that a wide diversity of gastric microbiota is encountered in healthy uncolonized subjects in comparison to $H$. pylori colonization, when studies reported both a lower abundance of other bacteria and a decrease in microbial diversity [41]. Therefore, we might state that $H$. pylori expresses a negative impact on both abundance and diversity of gastric bacterial community.

\subsection{Gastric Microenvironment in H. pylori-Negative/-Positive Pediatric Subjects}

In terms of pediatric patients, scarce information is available regarding the composition of gastric flora. A recent study performed on 346 children with symptoms suggesting $H$. pylori infection that aimed to assessed both $H$. pylori and non-H. pylori strains, pointed out $114 \mathrm{H}$. pylori positive cases and identified 366 non- $H$. pylori genera from 189 gastric biopsy specimens, 247 Gram-positive and 119 Gram-negative [42]. Moreover, the authors pointed out the following resistance rates for $\mathrm{H}$. pylori strains: $86.4 \%$ for metronidazole, $36.4 \%$ for clarithromycin, $31.8 \%$ for levofloxacin, and $22.7 \%$ for both tetracycline and amoxicillin, as well as 10 multidrug-resistant strains [42]. Non- $H$. pylori bacteria identified in this pediatric cohort presented generally higher resistance rates to the same antibiotics: $94.8 \%$ for metronidazole, $46.7 \%$ for clarithromycin, $42.6 \%$ for amoxicillin, $26.2 \%$ in case of tetracycline and $15.3 \%$ for levofloxacin. Moreover, 63 isolates were found to be multidrug-resistant [42]. The presence of non- $H$. pylori bacteria within the gastric ecosystem is particularly important since they might persistently act as an antigenic stimulus or establish a partnership with H. pylori in order to augment the subsequent inflammatory [43]. Therefore, the gastric microbiota composition in children with H. pylori infection is dominated by Streptoccocus, Neisseria, Rothia and Staphylococcus [42]. The same study pointed out that several ureasepositive non- $H$. pylori bacteria were present in pediatric gastric biopsy samples even in the absence of H. pylori, such as Staphylococcus aureus and epidermidis, Pseudomonas plecoglossicida, Acinetobacter johnsonii, Neisseria mucosa, Neisseria flavescens, Neisseria meningitidis, Neisseria perflava, Rothia mucilaginosa, and Micrococcus luteus [42]. Moreover, Staphylococcus haemolyticus, Staphylococcus epidermidis, Neisseria mucosa, Micrococcus luteus, Rothia dentocariosa, and Actinomyces naeslundii are well-known for their nitrate-reducing function with further implication in carcinogenesis due to the accumulation of nitrite and N-nitroso compounds in the gastric microenvironment [44]. Thus, we might hypothesize that gastric carcinogenesis has its origin in childhood when perturbation of stomach microecology homeostasis occurs.

Highly sensitive DNA-based detection methods suggest there may be many H. pylori carriers. This situation is particularly found in pediatric subjects since as we already mentioned the infection is usually acquired during childhood although they are not deemed always to develop the disease. Thus, a study performed on Spanish children proved that 17 of the children enrolled in this study were detected with a low abundance of H. pylori, carrying an average abundance of $0.45 \%$ within the gastric microbiota [45]. Moreover, a Chinese study revealed that five out of six individuals that were initially deemed $\mathrm{H}$. pylori negative were found to be healthy carriers after sequencing-based methods, with a low abundance varying between $0.04-0.67 \%$ [46]. Therefore, we might reconsider defining the presence of $H$. pylori as an infection and instead use colonization for a better approach of this topic since H. pylori might be considered a 'core member' or, according to some authors, the only 'true resident' of the gastric microbiota [37].

Studies performed on mice pointed out that gastric commensal bacteria have the ability to accelerate the inflammation caused by $H$. pylori, increasing the risk of carcinogenesis [47]. Concerning this topic, children diagnosed with $\mathrm{H}$. pylori infection were proven to harbor more diverse gastric bacterial communities when compared to infected adults [48]. The authors pointed out that infected children harbored lower abundance of Firmicutes and increased abundance of Proteobacteria along with higher proportions of Gammaproteobacteria in comparison to infected adult patients [48]. Regarding the genus level, Rothia was 
found to be less abundant in $H$. pylori positive children, while they harbored increased abundance of Haemophilus, Neisseria and an unidentified genus in Neisseriaceae family [48]. Thus, the assessment of changes in gastric commensal microbial community associated to H. pylori infection in children might be a cornerstone for the development of preventive and therapeutic strategies in order to reduce the persistence of this infection during adulthood and decrease the risk for long-term complications.

The interrelation between gastric commensal bacteria and age is undoubtable, and gastric microbiota might play a dichotomous role in promoting or suppressing H. pylorirelated gastropathy.

\subsection{Gastric Microenvironment in H. pylori-Negative/-Positive Adult Subjects}

It is a well-established fact that H. pylori is the most common inhabitant of the gastric environment, but another 6 genera were identified in patients with $H$. pylori associated disorders: Veillonella, Neisseria, Fusobacterium, Prevotella, Streptococcus and Haemophilus [37]. Most of these bacteria were identified also in other parts of the gastrointestinal tract, such as oral cavity, small or large bowel, and they adjusted their ability to survive the gastric environment. Therefore, a potential hypothesis is that $H$. pylori is influenced and influences the gastric microbial community, although when present it tends to predominate and the patient's final outcome depends on the network of coexisting bacteria [49]. This negative impact of $H$. pylori on the gastric microbiota is reversible according to Li et al., who proved that once eradicated, the gastric microbiota diversity can reach the levels of healthy uncolonized individuals [50]. The reciprocal relationship between H. pylori and gastric microbiota is therefore a decisive cornerstone for gastric carcinogenesis, and especially noncardia adenocarcinomas. Bacterial virulence represented by certain allotypes, i.e., CagA and VacA is one of the major factors involved in gastric carcinogenesis. Recent studies hypothesized that the eradication of this infection might not only prevent gastric cancer, but also minimize the risk of metachronous cancer in patients treated for early gastric cancer [51]. In terms of gastric carcinogenesis there are still certain variables that require further studies, such as the role of other bacteria belonging to the gastric microbiome since studies revealed a wide variety of cohabitants in conditions of hypo/achlorhydria along with $H$. pylori that also increase the risk for carcinogenesis due to their ability of nitrosamine forming with a well-documented oncogenic potential [52]. Thus, we hypothesize that an abnormal gastric microenvironment harbors an abnormal microbiota that additionally contributes to the H. pylori oncogenic potential.

In terms of $H$. pylori, multiple hypotheses have been proposed in order to explain the co-occurrence or mutual exclusion of microorganisms, such as the secretion of 20-aminoacid-long cecropin-like antibacterial peptides leading to a pro-inflammatory response and subsequent local acidosis; gastrin release; initial reduction of gastric $\mathrm{pH}$ in the acute phase resulting in an abundance of $H$. pylori that tends to predominate the gastric environment; a further increase of gastric $\mathrm{pH}$ associated to $H$. pylori chronic infection, which has exactly the opposite effect resulting in a microbial bloom that further inhibits the growth of $H$. pylori [49,53-55]. Moreover, the increase in gastric $\mathrm{pH}$ as a result of $H$. pylori chronic infection is a sign of atrophic gastritis that might influence itself the growth of certain microbes within the gastric environment. Thus, a study performed on patients with autoimmune chronic gastritis identified Gemella and Bosea as the main bacteria genera colonizing the stomachs of these patients [56], although the reports remain controversial. $H$. pylori influences and is influenced by the gastric microbial community.

3.4. Gastric Microenvironment in H. pylori-Negative/-Positive Subjects Treated with Proton Pump Inhibitors or Probiotics

Certain drugs that are also used in H. pylori eradication regimens were proved to impact the diversity and abundance of gastric microbial community. Proton pump inhibitors (PPIs), due to their ability to increase the gastric $\mathrm{pH}$, definitely result in considerable changes of gastric microbiota composition. Thus, a study performed on Israeli patients before and after PPIs administration proved that major changes occurred in gastric microbiota 
after 8 weeks of treatment consisting of a significant decrease in Flavobacteriaceae, Moraxellaceae, Comamonadaceae and Methylobacteriaceae, along with an increase in Erysipelotrichaceae and a family from the order Clostridiales [57]. Another study proved that normal healthy subject harbor similar gastric bacterial profiles to patients undergoing PPIs treatment, but underlined differences in terms of abundance encountering Prevotellaceae as the most abundant bacterial family in control group, followed by Streptococcaceae, Paraprevotellaceae and Fusobacteriaceae; while in PPIs group, the most abundant was Streptococcaceae, followed by Prevotellaceae, Campylobacteraceae, and Leptotrichiaceae [56]. Thus, PPIs clearly impact the composition, diversity and abundance of gastric bacterial community, but further studies on larger cohorts are required to elucidate the consequences of these changes.

Another class of therapeutic agents that has an effect on gastric microbiota are probiotics, but this topic is far to be understood. Nevertheless, a study that assessed Lactobacillus gasseri OLL2716 in patients with functional dyspepsia and healthy controls underlined that this therapy has the ability to change gastric fluid microbiota composition in these patients resulting in similar composition to that of healthy volunteers [58]. Thus, probiotics supplementation in H. pylori-positive patients undergoing standard regimens might be useful for an effective eradication.

\subsection{The Trialogue between H. pylori, Gastric Microbiota and Immune System}

A less explored side of this balance between H. pylori, gastric microbiota and immune system is represented by the effects of gastric bacterial community on immune responses with further crucial impact on $\mathrm{H}$. pylori persistence and its associated gastropathies. Gastric microbiome could be defined as a complex genomic content including microbial communities, host epithelium and host's immune system elements [59]. Moreover, similar to the statements of Nasr et al., we hypothesize that when dysbiosis occurs, i.e., changes in the number or diversity of gastric bacterial community, the commensal gastric bacteria become 'pathobionts', and along with dietary carcinogenic factors or other environmental factors, they play a key role in promoting carcinogenesis [59]. Thus, dysbiosis enhances growth and invasion of different pathogenic bacteria, further impairing the balance between the immune system and mucosal barrier. Pathogen recognition receptors (PRRs) are one of the main components of the immune system and they are trained in recognizing potentially pathogenic bacteria from harmless commensal community. Toll-like receptors (TLRs) represent an essential class of PRRs and they were identified on the surface of macrophages and dendritic cells [59] (Table 1).

Macrophages are well-known to accumulate within the gastric tissue as a response to $H$. pylori infection and the increase in their number is closely related to the disease severity and infection persistence $[81,82]$. Except of its chemotactic effect, $H$. pylori owns the ability to activate macrophages and induce the synthesis of interleukins (IL) 1, 6 and 8, but also tumor necrosis factor alpha (TNF $\alpha$ ), MIP-1 alpha and GRO-alpha, which further express a positive feedback on the recruitment and activation of additional macrophages and $\mathrm{T}$ cells [83,84]. In addition to their function of expressing TLRs, macrophages also secrete products with a negative impact on the gastric tissue in the setting of $H$. pylori infection, among which matrix metalloproteinases 9 and 2, which were proved to be elevated in patients with this infection, being involved in the destruction of gastric tissue $[84,85]$. It was proved that macrophages and monocytes act as essential coordinators of immune responses in the setting of $H$. pylori activating adaptive immunity through IL 12 synthesis, which will further stimulate Th1 cytokines such as IFN $\gamma$ [86]. Moreover, H. pylori plays a key role in favoring the migration of polymorphonuclear cells to the gastric mucosa via its virulence factor called H. pylori neutrophil-activating protein (HP-NAP) [86]. Another crucial role of this protein is the modulation of adaptive immunity by promoting the production of Th1 with subsequent increased synthesis of IFN $\gamma, \operatorname{TNF} \alpha$, and increasing the cytolytic activity of these cells [86]. Thus, we might state that both macrophages and neutrophils form a partnership with $H$. pylori in modulating the activity of Th1 cells with a positive feedback on Th1 cytokines production. Th1 lymphocyte response is also positively influenced by 
gastric epithelial cells that act as antigen presenting cells activating $\mathrm{CD}^{+}$Th cells [86]. Other $\mathrm{T}$ cell populations are involved in the immune response modulation to $H$. pylori such as Th17, which mainly produce IL 17A [87]. Furthermore, IL 17A promotes the expression of cytokines that act as chemoattractant for neutrophils from epithelial cells [88]. Aside from IL 17A, Th17 also secrete IL 17F, IL 21 and IL 22, which contribute to the recruitment of inflammatory cells [87]. Thus, Il 17/Th17 response promotes the persistence of the bacterium resulting in a chronic inflammatory process [86].

Table 1. The role of TLRs.

\begin{tabular}{|c|c|c|c|c|c|}
\hline No. & $\begin{array}{l}\text { Type of } \\
\text { TLR }\end{array}$ & $\begin{array}{l}\text { Components of } \\
\text { H. pylori Activate }\end{array}$ & Place & Results/Effects & Observations \\
\hline 1. & TLR 1 & - $\quad$ H. pylori surface & $\begin{array}{l}\text { Cell surface (Kawai et al., } \\
\text { 2011) [60] } \\
\text { Cell surface of bacteria, } \\
\text { fungi, parasites and Viruses } \\
\text { (Kawai et al., 2009) [61] }\end{array}$ & $\begin{array}{l}\text { - Binding partners for TLR2, aiding in its abil- } \\
\text { ity to recognize different ligands (Oliveira- } \\
\text { Nascimento et al., 2012) [62] } \\
\text { With TLR2 recognize a wide range of } \\
\text { pathogen-associated molecular patterns } \\
\text { (PAMPs) derived from various pathogens, } \\
\text { ranging from bacteria, fungi, parasites and } \\
\text { viruses (Kawai et al., 2009) [61] }\end{array}$ & - \\
\hline
\end{tabular}

\begin{tabular}{|c|c|c|c|c|c|}
\hline 2. & TLR 2 & $\begin{array}{ll}\text { binding to H. pylori } \\
\text { neutrophil-activating } \\
\text { protein (Rad et al., 2007; } \\
\text { Obonyo et al., 2007; } \\
\text { Takeda et al., 2005) [63-65] } \\
\text { nuclear factor- } \kappa \text { B activity } \\
\text { (Takenaka et al., 2004) [66] } \\
\text { TLR2/MyD88 signaling } \\
\text { (Echizen et al., 2016) [67] }\end{array}$ & $\begin{array}{l}\text { cell surface (Kawai et al., 2011) } \\
\text { [60] macrophages } \\
\text { culture gastric cells } \\
\text { monocyte cell surface of } \\
\text { bacteria, fungi, parasites and } \\
\text { viruses (Kawai et al., 2009) [61] }\end{array}$ & $\begin{array}{l}-\quad \text { recognition of H. pylori lipopolysaccharide } \\
\text { triggers a Th1 immune response } \\
\text { stimulate IL } 8 \\
\text { influence the strains of H. pylori that carry the } \\
\text { CagA pathogenicity island using coculturing } \\
\text { of monocytic THP-1 cells } \\
\text { pathogenesis of gastric cancer worldwide } \\
\text { recognize a wide range of pathogen-associated } \\
\text { molecular patterns (PAMPs) derived from var- } \\
\text { ious pathogens, ranging from bacteria, fungi, } \\
\text { parasites and viruses (Kawai et al., 2009) [61] }\end{array}$ & $\begin{array}{l}\text { studies on mice } \\
\text { study on mice }\end{array}$ \\
\hline 3. & TLR 3 & - $\quad$ H. pylori vesicles & $\begin{array}{c}\text { intracellular vesicles- } \\
\text { endoplasmatic reticulum } \\
\text { (Kawai et al., 2011) [60] } \\
\text { dendritic cells (Kawai et al., } \\
\text { 2009) [61] }\end{array}$ & $\begin{array}{l}\text { - in the recognition of microbial nucleic acids } \\
\text { (Kawai et al., 2011) [60] }\end{array}$ & - \\
\hline 4. & TLR 4 & $\begin{array}{l}\text { binding to } H . \text { pylori } \\
\text { neutrophil-activating } \\
\text { protein (Rad et al., 2007; } \\
\text { Obonyo et al., 2007) [63,64] } \\
\text { nuclear factor- } \kappa \text { B activity } \\
\text { (Takenaka et al., 2004) [66] }\end{array}$ & $\begin{array}{l}\text { MD-2 cell surface } \\
\text { (Kawai et al., 2011) [60] } \\
\text { macrophages apical and } \\
\text { basolateral levels of } \\
\text { the membrane } \\
\text { compartiment membrane of } \\
\text { Gram-negative bacteria, } \\
\text { (Kawai et al., 2009) [61] }\end{array}$ & $\begin{array}{l}\text { - } \quad \text { recognition of H. pylori lipopolysaccharide } \\
\text { stimulate IL } 8 \\
\text { modify the lipid A core of its LPS, represent- } \\
\text { ing a possible ligand for the immune complex } \\
\text { TLR4-MD2, in order to avoid TLR4 recognition } \\
\text { (Varga et al., 2017) [4] } \\
\text { inhibiting CD25 expression could decrease T } \\
\text { regulatory cells and, as a result, could suppress } \\
\text { H. pylori colonization (Gong et al., 2016) [68] } \\
\text { a potent immunostimulatory molecule and } \\
\text { causes septic shock (Kawai et al., 2009) [61] }\end{array}$ & studies on mice \\
\hline 5. & TLR 5 & $\begin{array}{l}\text { - } \quad \text { p38 MAP kinase signal- } \\
\text { ing pathway (Schmausser } \\
\text { et al., 2005) [69] }\end{array}$ & $\begin{array}{l}\text { cell surface (intestinal cells, } \\
\text { kidney \& bladder) } \\
\text {-monocyte (Kawai et al., } \\
\text { 2011) [60], (Kawai et al., } \\
\text { 2009) [61] }\end{array}$ & $\begin{array}{l}\text { recognition of bacterial flagellin [70] } \\
\text { influence the strains of H. pylori that carry the } \\
\text { CagA pathogenicity island using coculturing } \\
\text { of monocytic THP-1 cells } \\
\text { risk for gastric carcinoma (Xu et al., 2017) [71] } \\
\text { recognize flagellin, a protein component of } \\
\text { bacterial flagella (Kawai et al., 2009) [61] }\end{array}$ & - \\
\hline 6. & TLR 6 & $\begin{array}{l}\text { are expressed exclu- } \\
\text { sively on the cell surface } \\
\text { (Kawai et al., 2009) [61] }\end{array}$ & $\begin{array}{l}\text { cell surface (Kawai et al., } \\
\text { 2011) [60] } \\
\text { cell surface of bacteria, fungi, } \\
\text { parasites and viruses } \\
\text { (Kawai et al., 2009) [61] }\end{array}$ & $\begin{array}{l}\text { - binding partners for TLR2, aiding in its abil- } \\
\text { ity to recognize different ligands (Oliveira- } \\
\text { Nascimentoet al, 2012) [62] } \\
\text { recognize microbial membrane components } \\
\text { such as lipids, lipoproteins and proteins } \\
\text { (Kawai et al., 2009) [61] } \\
\text { with TLR2 recognize a wide range of } \\
\text { pathogen-associated molecular patterns } \\
\text { (PAMPs) derived from various pathogens, } \\
\text { ranging from bacteria, fungi, parasites and } \\
\text { viruses (Kawai et al., 2009) [61] }\end{array}$ & - \\
\hline
\end{tabular}


Table 1. Cont.

\begin{tabular}{|c|c|c|c|c|c|}
\hline No. & $\begin{array}{l}\text { Type of } \\
\text { TLR }\end{array}$ & $\begin{array}{l}\text { Components of } \\
\text { H. pylori Activate }\end{array}$ & Place & Results/Effects & Observations \\
\hline 7. & TLR 7 & - $\quad$ H. pylori RNA & $\begin{array}{l}\text { intracellular vesicles } \\
\text {-endoplasmic reticulum } \\
\text { (Kawai et al., 2011) [60] } \\
\text { plasmacytoid dendritic cells } \\
\text { (Kawai et al., 2009) [61] }\end{array}$ & $\begin{array}{l}\text { - induces pro-inflammatory cytokines in an } \\
\text { MyD88-dependent manner }\end{array}$ & - \\
\hline 8. & TLR 8 & - $\quad$ H. pylori RNA & $\begin{array}{l}\text { intracellular vesicles- } \\
\text { endoplasmatic reticulum } \\
\text { (Kawai et al., 2011) [60] }\end{array}$ & $\begin{array}{l}\text { - } \quad \text { induces pro-inflammatory cytokines in an } \\
\text { MyD88-dependent manner (Rad et al., 2009) [72] } \\
\text { - } \quad \text { stimulation of T regulatory cells hinders their } \\
\text { inhibitory action (Peng et al., 2005) [73] }\end{array}$ & - \\
\hline 9. & TLR 9 & $\begin{array}{l}\text { - } \quad \text { DNA of bacteria (Rad et al., } \\
\text { 2009 [72] } \\
\text { Suppression for H. pylori } \\
\text { infection Otani et al., } \\
2012[74]\end{array}$ & $\begin{array}{l}\text { intracellular vesicles- } \\
\text { endoplasmatic reticulum } \\
\text { (Kawai et al., 2011) [60] }\end{array}$ & $\begin{array}{l}\text { - } \text { recognizes bacterial DNA resulting in proin- } \\
\text { flammatory responses } \\
\text { suppresor for H. Pylori infection during the } \\
\text { acute phase of this infection-promoting the anti- } \\
\text { inflammatory signaling (Otani et al., 2012) [74] } \\
\text { promote pro-inflammatory cascades, and } \\
\text { eventually result in the development of } \\
\text { gastric cancer (Schmausser et al., 2004) [75] }\end{array}$ & $\begin{array}{l}\text { Murine model } \\
\text { mice }\end{array}$ \\
\hline 10. & TLR 10 & $\begin{array}{l}\text { a functional receptor in- } \\
\text { volved in innate immune } \\
\text { response triggered by } H \text {. } \\
\text { pylori (Nagashim et al., } \\
\text { 2015) [76] }\end{array}$ & $\begin{array}{l}\text { B Cells and Plasmacytoid } \\
\text { Dendritic Cells (Hasan et al., } \\
\text { 2005) [77] }\end{array}$ & $\begin{array}{l}\text { - TLR10 rs10004195 gene polymorphisms are as- } \\
\text { sociated with a higher risk of gastric cancer } \\
\text { Ravishankar Ram et al., 2015) [78] } \\
\text { Activates Gene Transcription through MyD88 } \\
\text { (Hasan et al., 2005) [77] }\end{array}$ & $\begin{array}{l}\text { TLR10 is not } \\
\text { functional in mice } \\
\text { because of a retro- } \\
\text { virus insertion } \\
\text { (Kawai et al., } \\
\text { 2009) [61] }\end{array}$ \\
\hline 11. & TLR 11 & $\begin{array}{l}\text { - } \quad \text { innate sensor for the Tox- } \\
\text { oplasma protein profilin } \\
\text { (Pifer et al., 2010) [79] }\end{array}$ & $\begin{array}{l}\text { intracellular vesicles- } \\
\text { endoplasmatic reticulum } \\
\text { (Kawai et al., 2011) [60] \& } \\
\text { dendritic cells, kidney \& } \\
\text { bladder (Pifer et al., 2010) [79], } \\
\text { (Kawai et al., 2009) [61] }\end{array}$ & $\begin{array}{l}\text { - regulates the activation of dendritic cells in re- } \\
\text { sponse to Toxoplasma gondii profilin and par- } \\
\text { asitic infection in vivo (Pifer et al., 2010) [79] }\end{array}$ & - \\
\hline 12. & TLR 12 & $\begin{array}{l}\text { - } \quad \text { reticulum-resident protein } \\
\text { UNC93B1 (Pifer et al., } \\
\text { 2010) [79] }\end{array}$ & $\begin{array}{l}\text { intracellular } \\
\text { vesicles-endoplasmatic } \\
\text { reticulum (Kawai et al., } \\
\text { 2011) [60] \& dendritic cells } \\
\text { (Pifer et al., 2010) [79] }\end{array}$ & $\begin{array}{l}\text { activation of dendritic cells in response to Tox- } \\
\text { oplasma gondii profilin and parasitic infection } \\
\text { in vivo (Pifer et al., 2010) [79] }\end{array}$ & - \\
\hline 13. & TLR 13 & $\begin{array}{l}\text { - } \quad \text { are expressed intracel- } \\
\text { lularly, (Blasius et al., } \\
\text { 2010) [80] }\end{array}$ & $\begin{array}{l}\text { endoplasmic reticulum, } \\
\text { multivesicular bodies, and } \\
\text { lysosomes (Blasius et al., } \\
\text { 2010) [80] }\end{array}$ & $\begin{array}{l}\text { TLR13 of mice are expressed intracellularly } \\
\text { within the endoplasmic reticulum (ER) } \\
\text { trafficking of Intracellular TLRs (Blasius et al., } \\
\text { 2010) [80] }\end{array}$ & mice \\
\hline
\end{tabular}

The activation of TLRs signaling pathways triggers the synthesis of inflammatory cytokines, chemokines, costimulatory molecules and antigen-presenting molecules [89]. Two main pathways were characterized in the activation of these receptors: myeloid differentiation primary response-88 (MyD88) and TIR-domain-containing adapter-inducing interferon $\beta$ (TRIF), which result in the expression of multiple cytokines, among which IL $1 \beta$ and 6, as well as interferons gamma (IFN $\gamma$ ) and gamma-induced protein 10 [90]. Moreover, the expression of MyD88 in macrophages was proved to be crucial for the induction of proinflammatory cytokines in the setting of $H$. pylori infection such as IL $6,1 \beta, 10$ and $12[63,64,91]$. In addition, IL 8 was also proved to be overexpressed in the presence of $H$. pylori according to a study performed on cultured gastric epithelial cells as a result of both TLR 2 and 4 activation by $H$. pylori heat shock protein 60, and subsequent augmentation of nuclear factor- $\mathrm{kB}$ activity [66]. Studies performed on mice proved that both TLR 2 and 4 are essential for these responses in macrophages [63,64]. It seems that these two TLRs interact and they are both involved in the recognition of H. pylori lipopolysaccharide, and that TLR2 also triggers a Th1 immune response since it binds to $H$. pylori neutrophil-activating protein [11,92]. It is also worth mentioning that dysbiosis-associated chronic inflammatory diseases, such as $H$. pylori-induced chronic gastritis result in an alteration of TLRs expression and subsequent downstream signaling. In normal settings, these TLRs have the ability to initiate fast and effective inflammatory 
responses for hindering microbial invasion [93], whereas $H$. pylori is well-documented to impair their normal functioning and to escape their recognition for establishing its persistence within the gastric tissue [11].

An association between TLR 4 signaling and T regulatory cells was underlined in mice, pointing out that the suppression of this signaling pathway results in an overcolonization of $H$. pylori due to an increase in T regulatory cells [68]. Additionally, it was emphasized that certain commensal intestinal bacteria have the ability to induce the differentiation of these $T$ regulatory cells locally by elaborating several products like short chain fatty acids $[94,95]$, and capsular polysaccharides [96,97]. The study of Brawner et al. indicated that the altered gastric microbiota due to H. pylori infection is involved in increasing the gastric $T$ regulatory cell response in children pointing out that $H$. pylori infected pediatric patients with subsequent altered gastric microbiota have significantly increased levels of IL 10 as compared to healthy children and H. pylori-positive adults due to the enhanced FOXP3 response, a protein involved in immune response [48]. The same pattern was observed for transforming growth factor (TGF) $\beta$, another anti-inflammatory cytokine, the expression of which was found to be elevated in children with $H$. pylori infection [48] since this infection contributes to both induction and maintenance of TGF $\beta$ expression $[98,99]$. Based on all these facts, the relationship between altered gastric microbiota and immune responses defined by mucosal $\mathrm{T}$ regulatory cells in children is incontestable. A potential mechanism for the long-term persistence of $H$. pylori infection that commonly occurs during childhood is based on the development of T regulatory-mediated tolerance to this bacterium, and further suppression of the effector T-cell responses [48]. TLR 5 is involved in the recognition of bacterial flagellin, through the p38 MAP kinase signaling pathway [11]. Moreover, this TLR together with TLR 2 were proven to influence the strains of H. pylori that carry the CagA pathogenicity island using coculturing of monocytic THP-1 cells [70]. TLR 9 recognizes bacterial DNA resulting in proinflammatory responses as it was proved on murine models [72]. Contrariwise, another study performed on mice showed that this TLR might also act as a suppressor for $H$. pylori infection during the acute phase of this infection since it is able to promote anti-inflammatory signaling [74]. Thus, the dichotomous role of TLR 9 seems to be influenced by the gastric microenvironment [4], emphasizing once more the essential role of gastric microbial community in immune responses even in pediatric patients.

Defensins, defined as short proteins belong to the family of mammalian antimicrobial peptides (AMPs) and they are known for their antimicrobial activity not only against bacteria, but also viruses, fungi and protozoa $[100,101]$. The expression of $\beta$-defensin 2 was found to be increased in the presence of bacteria [102]. Additionally, H. pylori induced gastritis was proved to be associated with considerable increase in $\beta$-defensin 2 as compared to non- $H$. pylori gastritis [103]. Innate host defense definitely owns a crucial role in eliminating gastric injurious factors since $\beta$-defensins were revealed to be increased in the setting of bacterial inflammation [104]. AMPs have a major influence on shaping the formation of gastrointestinal microbiota [34]. Nevertheless, this relationship is reciprocal since it is a well-documented fact that gastrointestinal microbiota regulates the secretion of defensins [34]. Multiple factors contribute to the modulation of $\beta$-defensins in the setting of $H$. pylori infection involving strain-dependent mechanisms and genetical factors, such as Cag pathogenicity island [105]. Gastric microbiota is closely related to gut commensal bacteria and in fact each part of the gastrointestinal microbiota is a small puzzle piece that functions optimally only when attached to each other. Therefore, gut microbiota is involved in the regulation of defensins production with a fast and effective role in deactivating or destroying microorganisms [106]. Furthermore, for a proper and effective protection against pathogens invasion, defensins must form a partnership with certain mediators, like cytokines, chemokines, supplements, antimicrobial proteins or cellular elements [107]. The crosstalk between $\mathrm{H}$. pylori and immune system in pediatric patients is far to be fully understood, but both innate and adaptive immune response play a key role in the host's response to this infection and might represent future targets for individualized therapies. 


\section{Conclusions}

Gastric homeostasis depends mostly on the appropriate interplay between the local commensal bacterial community and host's immune system. $H$. pylori, the most common bacterial infection worldwide usually acquired during childhood, is influenced and influences gastric microbiota. Moreover, host's immune system shapes the development of gastric microbiota and plays a decisive role in promoting or suppressing $H$. pylori infection. Nevertheless, H. pylori, gastric microbiota and host's immune responses form a complex puzzle that is far to be properly assembled requiring further studies especially in pediatric patients taking into account the age-related differences reported so far.

Author Contributions: L.E.M., C.O.M. and M.O.S. conceptualized and designed the study, drafted the initial manuscript, and reviewed and revised the manuscript. All authors approved the final manuscript as submitted and agree to be accountable for all aspects of the work. All authors have read and agreed to the published version of the manuscript.

Funding: This review received no external funding.

Institutional Review Board Statement: Not applicable.

Informed Consent Statement: Not applicable.

Acknowledgments: This research was partially supported by the internal research grant of the University of Medicine, Pharmacy, Sciences and Technology 'George Emil Palade' of Târgu Mureș, Romania, no. 293/6/14.01.2020: 'Evaluarea TLR2, TLR9 și NLRP3 în cazul gastritei determinate de infecția cu Helicobacter pylori la copii'.

Conflicts of Interest: The authors declare no conflict of interest.

\section{References}

1. Amieva, M.; Peek, R.M. Pathobiology of Helicobacter pylori-Induced Gastric Cancer. Gastroenterology 2016, 150, 64-78. [CrossRef] [PubMed]

2. Parkin, D.M.; Bray, F.; Ferlay, J.; Pisani, P. Global Cancer Statistics, 2002. CA Cancer J. Clin. 2005, 55, 74-108. [CrossRef]

3. McGuire, S. World Cancer Report 2014. Geneva, Switzerland: World Health Organization, International Agency for Research on Cancer, WHO Press, 2015. Adv. Nutr. 2016, 7, 418-419. [CrossRef] [PubMed]

4. Varga, M.G.; Peek, R.M. DNA Transfer and Toll-like Receptor Modulation by Helicobacter pylori. Curr. Top. Microbiol. Immunol. 2017, 400, 169-193. [CrossRef] [PubMed]

5. Skvarc, M.; Kopitar, A.N.; Kos, J.; Obermajer, N.; Tepes, B. Differences in the Antigens of Helicobacter pylori Strains Influence on the Innate Immune Response in the In Vitro Experiments. Available online: https:/ /www.hindawi.com/journals/mi/2014/287531/ (accessed on 17 August 2018).

6. Megraud, F.; Coenen, S.; Versporten, A.; Kist, M.; Lopez-Brea, M.; Hirschl, A.M.; Andersen, L.P.; Goossens, H.; Glupczynski, Y. Study Group participants Helicobacter pylori Resistance to Antibiotics in Europe and Its Relationship to Antibiotic Consumption. Gut 2013, 62, 34-42. [CrossRef] [PubMed]

7. Meliţ, L.E.; Mărginean, M.O.; Mocan, S.; Mărginean, C.O. The Usefulness of Inflammatory Biomarkers in Diagnosing Child and Adolescent's Gastritis: STROBE Compliant Article. Medicine 2019, 98, e16188. [CrossRef] [PubMed]

8. Săsăran, M.O.; Melit, L.E.; Mocan, S.; Ghiga, D.V.; Dobru, E.D. Pediatric Gastritis and Its Impact on Hematologic Parameters. Medicine 2020, 99, e21985. [CrossRef]

9. McCallion, W.A.; Murray, L.J.; Bailie, A.G.; Dalzell, A.M.; O'Reilly, D.P.; Bamford, K.B. Helicobacter pylori Infection in Children: Relation with Current Household Living Conditions. Gut 1996, 39, 18-21. [CrossRef]

10. Mišak, Z.; Hojsak, I.; Homan, M. Review: Helicobacter pylori in Pediatrics. Helicobacter 2019, 24 (Suppl. 1), e12639. [CrossRef] [PubMed]

11. Meliț, L.E.; Mărginean, C.O.; Mărginean, C.D.; Mărginean, M.O. The Relationship between Toll-like Receptors and Helicobacter pylori-Related Gastropathies: Still a Controversial Topic. Available online: https://www.hindawi.com/journals/jir/2019/81970 48/abs/ (accessed on 9 February 2019).

12. Pellicano, R.; Ribaldone, D.G.; Fagoonee, S.; Astegiano, M.; Saracco, G.M.; Mégraud, F. A 2016 Panorama of Helicobacter pylori Infection: Key Messages for Clinicians. Panminerva Med. 2016, 58, 304-317.

13. Sijun, H.; Yong, X. Helicobacter pylori Vaccine: Mucosal Adjuvant \& Delivery Systems. Indian J. Med. Res. 2009, 130, 115-124. [PubMed]

14. Tang, M.Y.L.; Chung, P.H.Y.; Chan, H.Y.; Tam, P.K.H.; Wong, K.K. Recent Trends in the Prevalence of Helicobacter pylori in Symptomatic Children: A 12-Year Retrospective Study in a Tertiary Centre. J. Pediatr. Surg. 2019, 54, 255-257. [CrossRef] [PubMed] 
15. Shiferaw, G.; Abera, D. Magnitude of Helicobacter pylori and Associated Risk Factors among Symptomatic Patients Attending at Jasmin Internal Medicine and Pediatrics Specialized Private Clinic in Addis Ababa City, Ethiopia. BMC Infect. Dis. 2019, 19, 118. [CrossRef] [PubMed]

16. Szaflarska-Popławska, A.; Soroczyńska-Wrzyszcz, A. Prevalence of Helicobacter pylori Infection among Junior High School Students in Grudziadz, Poland. Helicobacter 2019, 24, e12552. [CrossRef]

17. Zhou, Y.; Ye, Z.; Huang, J.; Huang, Y.; Yan, W.; Zhang, Y. High Prevalence and Low Spontaneous Eradication Rate of Helicobacter pylori Infection among Schoolchildren Aged 7-12 Years. Acta Paediatr. 2018, 107, 1624-1628. [CrossRef] [PubMed]

18. Aguilar-Luis, M.A.; Palacios-Cuervo, F.; Espinal-Reyes, F.; Calderón-Rivera, A.; Levy-Blitchtein, S.; Palomares-Reyes, C.; Silva-Caso, W.; Zavaleta-Gavidia, V.; Bazán-Mayra, J.; Cornejo-Tapia, A.; et al. Highly Clarithromycin-Resistant Helicobacter pylori Infection in Asymptomatic Children from a Rural Community of Cajamarca-Peru. BMC Res. Notes 2018, 11, 809. [CrossRef] [PubMed]

19. Toscano, E.P.; Madeira, F.F.; Dutra-Rulli, M.P.; Gonçalves, L.O.M.; Proença, M.A.; Borghi, V.S.; Cadamuro, A.C.T.; Mazzale, G.W.; Acayaba, R.; Silva, A.E. Epidemiological and Clinical-Pathological Aspects of Helicobacter pylori Infection in Brazilian Children and Adults. Gastroenterol. Res Pr. 2018, 2018, 8454125. [CrossRef] [PubMed]

20. Kakiuchi, T.; Matsuo, M.; Endo, H.; Nakayama, A.; Sato, K.; Takamori, A.; Sasaki, K.; Takasaki, M.; Hara, M.; Sakata, Y.; et al. A Helicobacter pylori Screening and Treatment Program to Eliminate Gastric Cancer among Junior High School Students in Saga Prefecture: A Preliminary Report. J. Gastroenterol. 2019, 54, 699-707. [CrossRef]

21. Meliţ, L.E.; Mărginean, C.O.; Bănescu, C.; Bogliş, A.; Mocan, S.; Iancu, M. The Relationship between TLR4 Rs4986790 and Rs4986791 Gene Polymorphisms and Helicobacter pylori Infection in Children with Gastritis. Pathol. Res. Pract. 2019, $215,152692$. [CrossRef] [PubMed]

22. Tang, Z.; Shi, J.; Ji, M.; Shi, P.; Huang, Z.; Huang, Y. The Characteristics of 83 Giant Peptic Ulcers in Chinese Children: Evaluation and Follow-Up. Saudi J. Gastroenterol. 2018, 24, 360-364. [CrossRef]

23. Meliţ, L.E.; Mărginean, C.O.; Mocanu, S.; Mărginean, M.O. A Rare Case of Iron-Pill Induced Gastritis in a Female Teenager: A Case Report and a Review of the Literature. Medicine 2017, 96, e7550. [CrossRef] [PubMed]

24. Jones, N.L.; Koletzko, S.; Goodman, K.; Bontems, P.; Cadranel, S.; Casswall, T.; Czinn, S.; Gold, B.D.; Guarner, J.; Elitsur, Y.; et al. Joint ESPGHAN/NASPGHAN Guidelines for the Management of Helicobacter pylori in Children and Adolescents (Update 2016). J. Pediatr. Gastroenterol. Nutr. 2017, 64, 991-1003. [CrossRef] [PubMed]

25. Silva, G.M.; Silva, H.M.; Nascimento, J.; Gonçalves, J.-P.; Pereira, F.; Lima, R. Helicobacter pylori Antimicrobial Resistance in a Pediatric Population. Helicobacter 2018, 23, e12528. [CrossRef] [PubMed]

26. Dehghani, S.M.; Nazari, A.; Javaherizadeh, H. Effect of Sequential Therapy on Treatment of Helicobacter pylori Infection in Children. Rev. Gastroenterol. Peru 2018, 38, 128-130.

27. Fang, H.-R.; Zhang, G.-Q.; Cheng, J.-Y.; Li, Z.-Y. Efficacy of Lactobacillus-Supplemented Triple Therapy for Helicobacter pylori Infection in Children: A Meta-Analysis of Randomized Controlled Trials. Eur. J. Pediatr. 2019, 178, 7-16. [CrossRef]

28. Eslami, M.; Yousefi, B.; Kokhaei, P.; Jazayeri Moghadas, A.; Sadighi Moghadam, B.; Arabkari, V.; Niazi, Z. Are Probiotics Useful for Therapy of Helicobacter pylori Diseases? Comp. Immunol. Microbiol. Infect. Dis. 2019, 64, 99-108. [CrossRef]

29. Feng, J.-R.; Wang, F.; Qiu, X.; McFarland, L.V.; Chen, P.-F.; Zhou, R.; Liu, J.; Zhao, Q.; Li, J. Efficacy and Safety of ProbioticSupplemented Triple Therapy for Eradication of Helicobacter pylori in Children: A Systematic Review and Network Meta-Analysis. Eur. J. Clin. Pharmacol. 2017, 73, 1199-1208. [CrossRef]

30. Matsushima, K.; Isomoto, H.; Inoue, N.; Nakayama, T.; Hayashi, T.; Nakayama, M.; Nakao, K.; Hirayama, T.; Kohno, S. MicroRNA Signatures in Helicobacter pylori-Infected Gastric Mucosa. Int. J. Cancer 2011, 128, 361-370. [CrossRef]

31. Cortés-Márquez, A.C.; Mendoza-Elizalde, S.; Arenas-Huertero, F.; Trillo-Tinoco, J.; Valencia-Mayoral, P.; Consuelo-Sánchez, A.; Zarate-Franco, J.; Dionicio-Avendaño, A.R.; de Jesús Herrera-Esquivel, J.; Recinos-Carrera, E.G.; et al. Differential Expression of MiRNA-146a and MiRNA-155 in Gastritis Induced by Helicobacter pylori Infection in Paediatric Patients, Adults, and an Animal Model. BMC Infect. Dis. 2018, 18, 463. [CrossRef]

32. Shimoda, A.; Ueda, K.; Nishiumi, S.; Murata-Kamiya, N.; Mukai, S.-A.; Sawada, S.; Azuma, T.; Hatakeyama, M.; Akiyoshi, K. Exosomes as Nanocarriers for Systemic Delivery of the Helicobacter pylori Virulence Factor CagA. Sci. Rep. 2016, 6, 18346. [CrossRef]

33. Quintana-Hayashi, M.P.; Rocha, R.; Padra, M.; Thorell, A.; Jin, C.; Karlsson, N.G.; Roxo-Rosa, M.; Oleastro, M.; Lindén, S.K. BabA-Mediated Adherence of Pediatric Ulcerogenic H. pylori Strains to Gastric Mucins at Neutral and Acidic PH. Virulence 2018, 9, 1699-1717. [CrossRef] [PubMed]

34. Pero, R.; Brancaccio, M.; Laneri, S.; Biasi, M.-G.D.; Lombardo, B.; Scudiero, O. A Novel View of Human Helicobacter pylori Infections: Interplay between Microbiota and Beta-Defensins. Biomolecules 2019, 9, 237. [CrossRef] [PubMed]

35. Yang, I.; Nell, S.; Suerbaum, S. Survival in Hostile Territory: The Microbiota of the Stomach. FEMS Microbiol. Rev. 2013, 37, 736-761. [CrossRef] [PubMed]

36. Nardone, G.; Compare, D. The Human Gastric Microbiota: Is It Time to Rethink the Pathogenesis of Stomach Diseases? United Eur. Gastroenterol. J. 2015, 3, 255-260. [CrossRef] [PubMed]

37. Spiegelhauer, M.R.; Kupcinskas, J.; Johannesen, T.B.; Urba, M.; Skieceviciene, J.; Jonaitis, L.; Frandsen, T.H.; Kupcinskas, L.; Fuursted, K.; Andersen, L.P. Transient and Persistent Gastric Microbiome: Adherence of Bacteria in Gastric Cancer and Dyspeptic Patient Biopsies after Washing. J. Clin. Med. 2020, 9, 1882. [CrossRef] [PubMed] 
38. Bassis, C.M.; Erb-Downward, J.R.; Dickson, R.P.; Freeman, C.M.; Schmidt, T.M.; Young, V.B.; Beck, J.M.; Curtis, J.L.; Huffnagle, G.B. Analysis of the Upper Respiratory Tract Microbiotas as the Source of the Lung and Gastric Microbiotas in Healthy Individuals. mBio 2015, 6, e00037. [CrossRef] [PubMed]

39. Bashir, M.; Prietl, B.; Tauschmann, M.; Mautner, S.I.; Kump, P.K.; Treiber, G.; Wurm, P.; Gorkiewicz, G.; Högenauer, C.; Pieber, T.R. Effects of High Doses of Vitamin D3 on Mucosa-Associated Gut Microbiome Vary between Regions of the Human Gastrointestinal Tract. Eur. J. Nutr. 2016, 55, 1479-1489. [CrossRef]

40. Stearns, J.C.; Lynch, M.D.J.; Senadheera, D.B.; Tenenbaum, H.C.; Goldberg, M.B.; Cvitkovitch, D.G.; Croitoru, K.; Moreno-Hagelsieb, G.; Neufeld, J.D. Bacterial Biogeography of the Human Digestive Tract. Sci. Rep. 2011, 1, 170. [CrossRef]

41. Bravo, D.; Hoare, A.; Soto, C.; Valenzuela, M.A.; Quest, A.F. Helicobacter pylori in Human Health and Disease: Mechanisms for Local Gastric and Systemic Effects. World J. Gastroenterol. 2018, 24, 3071-3089. [CrossRef]

42. Guo, C.; Liu, F.; Zhu, L.; Wu, F.; Cui, G.; Xiong, Y.; Wang, Q.; Yin, L.; Wang, C.; Wang, H.; et al. Analysis of Culturable Microbiota Present in the Stomach of Children with Gastric Symptoms. Braz. J. Microbiol. 2019, 50, 107-115. [CrossRef]

43. Rook, G.; Bäckhed, F.; Levin, B.R.; McFall-Ngai, M.J.; McLean, A.R. Evolution, Human-Microbe Interactions, and Life History Plasticity. Lancet 2017, 390, 521-530. [CrossRef]

44. Ferreira, R.M.; Pereira-Marques, J.; Pinto-Ribeiro, I.; Costa, J.L.; Carneiro, F.; Machado, J.C.; Figueiredo, C. Gastric Microbial Community Profiling Reveals a Dysbiotic Cancer-Associated Microbiota. Gut 2018, 67, 226-236. [CrossRef]

45. Llorca, L.; Pérez-Pérez, G.; Urruzuno, P.; Martinez, M.J.; Iizumi, T.; Gao, Z.; Sohn, J.; Chung, J.; Cox, L.; Simón-Soro, A.; et al. Characterization of the Gastric Microbiota in a Pediatric Population According to Helicobacter pylori Status. Pediatr. Infect. Dis. J. 2017, 36, 173-178. [CrossRef]

46. Wang, L.-L.; Yu, X.-J.; Zhan, S.-H.; Jia, S.-J.; Tian, Z.-B.; Dong, Q.-J. Participation of Microbiota in the Development of Gastric Cancer. World J. Gastroenterol. 2014, 20, 4948-4952. [CrossRef]

47. Lofgren, J.L.; Whary, M.T.; Ge, Z.; Muthupalani, S.; Taylor, N.S.; Mobley, M.; Potter, A.; Varro, A.; Eibach, D.; Suerbaum, S.; et al. Lack of Commensal Flora in Helicobacter pylori-Infected INS-GAS Mice Reduces Gastritis and Delays Intraepithelial Neoplasia. Gastroenterology 2011, 140, 210-220. [CrossRef]

48. Brawner, K.M.; Kumar, R.; Serrano, C.A.; Ptacek, T.; Lefkowitz, E.; Morrow, C.D.; Zhi, D.; Kyanam-Kabir-Baig, K.R.; Smythies, L.E.; Harris, P.R.; et al. Helicobacter pylori Infection Is Associated with an Altered Gastric Microbiota in Children. Mucosal Immunol. 2017, 10, 1169-1177. [CrossRef]

49. Das, A.; Pereira, V.; Saxena, S.; Ghosh, T.S.; Anbumani, D.; Bag, S.; Das, B.; Nair, G.B.; Abraham, P.; Mande, S.S. Gastric Microbiome of Indian Patients with Helicobacter pylori Infection, and Their Interaction Networks. Sci. Rep. 2017, 7, 15438. [CrossRef]

50. Li, T.H.; Qin, Y.; Sham, P.C.; Lau, K.S.; Chu, K.-M.; Leung, W.K. Alterations in Gastric Microbiota After H. pylori Eradication and in Different Histological Stages of Gastric Carcinogenesis. Sci. Rep. 2017, 7, 44935. [CrossRef]

51. Choi, I.J.; Kook, M.-C.; Kim, Y.-I.; Cho, S.-J.; Lee, J.Y.; Kim, C.G.; Park, B.; Nam, B.-H. Helicobacter pylori Therapy for the Prevention of Metachronous Gastric Cancer. N. Engl. J. Med. 2018, 378, 1085-1095. [CrossRef] [PubMed]

52. Schulz, C.; Schütte, K.; Malfertheiner, P. Helicobacter pylori and Other Gastric Microbiota in Gastroduodenal Pathologies. Dig. Dis. 2016, 34, 210-216. [CrossRef]

53. Bylund, J.; Christophe, T.; Boulay, F.; Nyström, T.; Karlsson, A.; Dahlgren, C. Proinflammatory Activity of a Cecropin-like Antibacterial Peptide from Helicobacter pylori. Antimicrob. Agents Chemother. 2001, 45, 1700-1704. [CrossRef] [PubMed]

54. Lardner, A. The Effects of Extracellular PH on Immune Function. J. Leukoc. Biol. 2001, 69, 522-530. [PubMed]

55. Graham, D.Y.; Lew, G.M.; Lechago, J. Antral G-Cell and D-Cell Numbers in Helicobacter pylori Infection: Effect of H. pylori Eradication. Gastroenterology 1993, 104, 1655-1660. [CrossRef]

56. Parsons, B.N.; Ijaz, U.Z.; D’Amore, R.; Burkitt, M.D.; Eccles, R.; Lenzi, L.; Duckworth, C.A.; Moore, A.R.; Tiszlavicz, L.; Varro, A.; et al. Comparison of the Human Gastric Microbiota in Hypochlorhydric States Arising as a Result of Helicobacter pylori-Induced Atrophic Gastritis, Autoimmune Atrophic Gastritis and Proton Pump Inhibitor Use. PLoS Pathog. 2017, 13, e1006653. [CrossRef]

57. Amir, I.; Konikoff, F.M.; Oppenheim, M.; Gophna, U.; Half, E.E. Gastric Microbiota Is Altered in Oesophagitis and Barrett's Oesophagus and Further Modified by Proton Pump Inhibitors. Environ. Microbiol. 2014, 16, 2905-2914. [CrossRef] [PubMed]

58. Igarashi, M.; Nakae, H.; Matsuoka, T.; Takahashi, S.; Hisada, T.; Tomita, J.; Koga, Y. Alteration in the Gastric Microbiota and Its Restoration by Probiotics in Patients with Functional Dyspepsia. BMJ Open Gastroenterol. 2017, 4, e000144. [CrossRef] [PubMed]

59. Nasr, R.; Shamseddine, A.; Mukherji, D.; Nassar, F.; Temraz, S. The Crosstalk between Microbiome and Immune Response in Gastric Cancer. Int. J. Mol. Sci. 2020, 21, 6586. [CrossRef] [PubMed]

60. Kawai, T.; Akira, S. Toll-like Receptors and Their Crosstalk with Other Innate Receptors in Infection and Immunity. Immunity 2011, 34, 637-650. [CrossRef] [PubMed]

61. Kawai, T.; Akira, S. The Roles of TLRs, RLRs and NLRs in Pathogen Recognition. Int. Immunol. 2009, 21, 317-337. [CrossRef]

62. Oliveira-Nascimento, L.; Massari, P.; Wetzler, L.M. The Role of TLR2 in Infection and Immunity. Front. Immunol. 2012, 3, 79. [CrossRef]

63. Rad, R.; Brenner, L.; Krug, A.; Voland, P.; Mages, J.; Lang, R.; Schwendy, S.; Reindl, W.; Dossumbekova, A.; Ballhorn, W.; et al. Tolllike Receptor-Dependent Activation of Antigen-Presenting Cells Affects Adaptive Immunity to Helicobacter pylori. Gastroenterology 2007, 133, 150-163.e3. [CrossRef] [PubMed] 
64. Obonyo, M.; Sabet, M.; Cole, S.P.; Ebmeyer, J.; Uematsu, S.; Akira, S.; Guiney, D.G. Deficiencies of Myeloid Differentiation Factor 88, Toll-like Receptor 2 (TLR2), or TLR4 Produce Specific Defects in Macrophage Cytokine Secretion Induced by Helicobacter pylori. Infect. Immun. 2007, 75, 2408-2414. [CrossRef]

65. Takeda, K.; Akira, S. Toll-like Receptors in Innate Immunity. Int. Immunol. 2005, 17, 1-14. [CrossRef]

66. Takenaka, R.; Yokota, K.; Ayada, K.; Mizuno, M.; Zhao, Y.; Fujinami, Y.; Lin, S.-N.; Toyokawa, T.; Okada, H.; Shiratori, Y.; et al. Helicobacter pylori Heat-Shock Protein 60 Induces Inflammatory Responses through the Toll-like Receptor-Triggered Pathway in Cultured Human Gastric Epithelial Cells. Microbiology 2004, 150, 3913-3922. [CrossRef]

67. Echizen, K.; Hirose, O.; Maeda, Y.; Oshima, M. Inflammation in Gastric Cancer: Interplay of the COX-2/Prostaglandin E2 and Toll-like Receptor/MyD88 Pathways. Cancer Sci. 2016, 107, 391-397. [CrossRef]

68. Gong, Y.; Tao, L.; Jing, L.; Liu, D.; Hu, S.; Liu, W.; Zhou, N.; Xie, Y. Association of TLR4 and Treg in Helicobacter pylori Colonization and Inflammation in Mice. PLoS ONE 2016, 11, e0149629. [CrossRef]

69. Schmausser, B.; Andrulis, M.; Endrich, S.; Müller-Hermelink, H.-K.; Eck, M. Toll-like Receptors TLR4, TLR5 and TLR9 on Gastric Carcinoma Cells: An Implication for Interaction with Helicobacter pylori. Int. J. Med. Microbiol. 2005, 295, 179-185. [CrossRef]

70. Guo, Q.; Zhu, J.; Xia, B. Polymorphism of CD14 Gene but Not the Mutation of TLR4 Gene Is Associated with Colorectal Cancer in Chinese Patients. J. Gastroenterol. Hepatol. 2006, 21, 92-97. [CrossRef] [PubMed]

71. Xu, T.; Fu, D.; Ren, Y.; Dai, Y.; Lin, J.; Tang, L.; Ji, J. Genetic Variations of TLR5 Gene Interacted with Helicobacter pylori Infection among Carcinogenesis of Gastric Cancer. Oncotarget 2017, 8, 31016-31022. [CrossRef]

72. Rad, R.; Ballhorn, W.; Voland, P.; Eisenächer, K.; Mages, J.; Rad, L.; Ferstl, R.; Lang, R.; Wagner, H.; Schmid, R.M.; et al. Extracellular and Intracellular Pattern Recognition Receptors Cooperate in the Recognition of Helicobacter pylori. Gastroenterology 2009, 136, 2247-2257. [CrossRef] [PubMed]

73. Peng, G.; Guo, Z.; Kiniwa, Y.; Voo, K.S.; Peng, W.; Fu, T.; Wang, D.Y.; Li, Y.; Wang, H.Y.; Wang, R.-F. Toll-like Receptor 8-Mediated Reversal of CD4+ Regulatory T Cell Function. Science 2005, 309, 1380-1384. [CrossRef]

74. Otani, K.; Tanigawa, T.; Watanabe, T.; Nadatani, Y.; Sogawa, M.; Yamagami, H.; Shiba, M.; Watanabe, K.; Tominaga, K.; Fujiwara, Y.; et al. Toll-like Receptor 9 Signaling Has Anti-Inflammatory Effects on the Early Phase of Helicobacter pylori-Induced Gastritis. Biochem. Biophys. Res. Commun. 2012, 426, 342-349. [CrossRef]

75. Schmausser, B.; Andrulis, M.; Endrich, S.; Lee, S.K.; Josenhans, C.; Müller-Hermelink, H.-K.; Eck, M. Expression and Subcellular Distribution of Toll-like Receptors TLR4, TLR5 and TLR9 on the Gastric Epithelium in Helicobacter pylori Infection. Clin. Exp. Immunol. 2004, 136, 521-526. [CrossRef]

76. Nagashima, H.; Iwatani, S.; Cruz, M.; Jiménez Abreu, J.A.; Uchida, T.; Mahachai, V.; Vilaichone, R.-K.; Graham, D.Y.; Yamaoka, Y. Toll-like Receptor 10 in Helicobacter pylori Infection. J. Infect. Dis. 2015, 212, 1666-1676. [CrossRef]

77. Hasan, U.; Chaffois, C.; Gaillard, C.; Saulnier, V.; Merck, E.; Tancredi, S.; Guiet, C.; Brière, F.; Vlach, J.; Lebecque, S.; et al. Human TLR10 Is a Functional Receptor, Expressed by B Cells and Plasmacytoid Dendritic Cells, Which Activates Gene Transcription through MyD88. J. Immunol. 2005, 174, 2942-2950. [CrossRef]

78. Ravishankar Ram, M.; Goh, K.L.; Leow, A.H.R.; Poh, B.H.; Loke, M.F.; Harrison, R.; Shankar, E.M.; Vadivelu, J. Polymorphisms at Locus 4p14 of Toll-Like Receptors TLR-1 and TLR-10 Confer Susceptibility to Gastric Carcinoma in Helicobacter pylori Infection. PLoS ONE 2015, 10, e0141865. [CrossRef]

79. Pifer, R.; Benson, A.; Sturge, C.R.; Yarovinsky, F. UNC93B1 Is Essential for TLR11 Activation and IL-12-Dependent Host Resistance to Toxoplasma Gondii. J. Biol. Chem. 2011, 286, 3307-3314. [CrossRef] [PubMed]

80. Blasius, A.L.; Beutler, B. Intracellular Toll-like Receptors. Immunity 2010, 32, 305-315. [CrossRef]

81. Krauss-Etschmann, S.; Gruber, R.; Plikat, K.; Antoni, I.; Demmelmair, H.; Reinhardt, D.; Koletzko, S. Increase of AntigenPresenting Cells in the Gastric Mucosa of Helicobacter pylori-Infected Children. Helicobacter 2005, 10, 214-222. [CrossRef] [PubMed]

82. Suzuki, T.; Kato, K.; Ohara, S.; Noguchi, K.; Sekine, H.; Nagura, H.; Shimosegawa, T. Localization of Antigen-Presenting Cells in Helicobacter pylori-Infected Gastric Mucosa. Pathol. Int. 2002, 52, 265-271. [CrossRef] [PubMed]

83. Eck, M.; Schmausser, B.; Scheller, K.; Toksoy, A.; Kraus, M.; Menzel, T.; Müller-Hermelink, H.K.; Gillitzer, R. CXC Chemokines Gro(Alpha)/IL-8 and IP-10/MIG in Helicobacter pylori Gastritis. Clin. Exp. Immunol. 2000, 122, 192-199. [CrossRef]

84. Kaparakis, M.; Walduck, A.K.; Price, J.D.; Pedersen, J.S.; van Rooijen, N.; Pearse, M.J.; Wijburg, O.L.C.; Strugnell, R.A. Macrophages Are Mediators of Gastritis in Acute Helicobacter pylori Infection in C57BL/6 Mice. Infect. Immun. 2008, 76, 2235-2239. [CrossRef] [PubMed]

85. Bergin, P.J.; Anders, E.; Sicheng, W.; Erik, J.; Jennie, A.; Hans, L.; Pierre, M.; Qiang, P.-H.; Marianne, Q.-J. Increased Production of Matrix Metalloproteinases in Helicobacter pylori-Associated Human Gastritis. Helicobacter 2004, 9, 201-210. [CrossRef] [PubMed]

86. Peek, R.M.; Fiske, C.; Wilson, K.T. Role of Innate Immunity in Helicobacter pylori-Induced Gastric Malignancy. Physiol. Rev. 2010, 90, 831-858. [CrossRef]

87. Bagheri, N.; Salimzadeh, L.; Shirzad, H. The Role of T Helper 1-Cell Response in Helicobacter pylori-Infection. Microb. Pathog. 2018, 123, 1-8. [CrossRef] [PubMed]

88. Bagheri, N.; Azadegan-Dehkordi, F.; Shirzad, H.; Rafieian-Kopaei, M.; Rahimian, G.; Razavi, A. The Biological Functions of IL-17 in Different Clinical Expressions of Helicobacter pylori-Infection. Microb. Pathog. 2015, 81, 33-38. [CrossRef] [PubMed]

89. Chaudhary, P.M.; Ferguson, C.; Nguyen, V.; Nguyen, O.; Massa, H.F.; Eby, M.; Jasmin, A.; Trask, B.J.; Hood, L.; Nelson, P.S Cloning and Characterization of Two Toll/Interleukin-1 Receptor-like Genes TIL3 and TIL4: Evidence for a Multi-Gene Receptor Family in Humans. Blood 1998, 91, 4020-4027. [CrossRef] [PubMed] 
90. Piras, V.; Selvarajoo, K. Beyond MyD88 and TRIF Pathways in Toll-Like Receptor Signaling. Front. Immunol. 2014, 5, 70. [CrossRef] [PubMed]

91. Müller, A.; Oertli, M.; Arnold, I.C. H. pylori Exploits and Manipulates Innate and Adaptive Immune Cell Signaling Pathways to Establish Persistent Infection. Cell Commun. Signal. 2011, 9, 25. [CrossRef]

92. Amedei, A.; Cappon, A.; Codolo, G.; Cabrelle, A.; Polenghi, A.; Benagiano, M.; Tasca, E.; Azzurri, A.; D’Elios, M.M.; Del Prete, G.; et al. The Neutrophil-Activating Protein of Helicobacter pylori Promotes Th1 Immune Responses. J. Clin. Investig. 2006, 116, 1092-1101. [CrossRef]

93. Toor, D.; Wsson, M.K.; Kumar, P.; Karthikeyan, G.; Kaushik, N.K.; Goel, C.; Singh, S.; Kumar, A.; Prakash, H. Dysbiosis Disrupts Gut Immune Homeostasis and Promotes Gastric Diseases. Int. J. Mol. Sci. 2019, 20, 2432. [CrossRef] [PubMed]

94. Smith, P.M.; Howitt, M.R.; Panikov, N.; Michaud, M.; Gallini, C.A.; Bohlooly-y, M.; Glickman, J.N.; Garrett, W.S. The Microbial Metabolites, Short-Chain Fatty Acids, Regulate Colonic Treg Cell Homeostasis. Science 2013, 341, 569-573. [CrossRef] [PubMed]

95. Arpaia, N.; Campbell, C.; Fan, X.; Dikiy, S.; van der Veeken, J.; de Roos, P.; Liu, H.; Cross, J.R.; Pfeffer, K.; Coffer, P.J.; et al. Metabolites Produced by Commensal Bacteria Promote Peripheral Regulatory T-Cell Generation. Nature 2013, 504, $451-455$. [CrossRef] [PubMed]

96. Shen, Y.; Giardino Torchia, M.L.; Lawson, G.W.; Karp, C.L.; Ashwell, J.D.; Mazmanian, S.K. Outer Membrane Vesicles of a Human Commensal Mediate Immune Regulation and Disease Protection. Cell Host Microbe 2012, 12, 509-520. [CrossRef] [PubMed]

97. Chu, H.; Khosravi, A.; Kusumawardhani, I.P.; Kwon, A.H.K.; Vasconcelos, A.C.; Cunha, L.D.; Mayer, A.E.; Shen, Y.; Wu, W.-L.; Kambal, A.; et al. Gene-Microbiota Interactions Contribute to the Pathogenesis of Inflammatory Bowel Disease. Science 2016, 352, 1116-1120. [CrossRef] [PubMed]

98. Uno, K.; Kato, K.; Atsumi, T.; Suzuki, T.; Yoshitake, J.; Morita, H.; Ohara, S.; Kotake, Y.; Shimosegawa, T.; Yoshimura, T. Toll-like Receptor (TLR) 2 Induced through TLR4 Signaling Initiated by Helicobacter pylori Cooperatively Amplifies INOS Induction in Gastric Epithelial Cells. Am. J. Physiol. Gastrointest. Liver Physiol. 2007, 293, G1004-G1012. [CrossRef]

99. Chochi, K.; Ichikura, T.; Kinoshita, M.; Majima, T.; Shinomiya, N.; Tsujimoto, H.; Kawabata, T.; Sugasawa, H.; Ono, S.; Seki, S.; et al. Helicobacter pylori Augments Growth of Gastric Cancers via the Lipopolysaccharide-Toll-like Receptor 4 Pathway Whereas Its Lipopolysaccharide Attenuates Antitumor Activities of Human Mononuclear Cells. Clin. Cancer Res. 2008, 14, $2909-2917$. [CrossRef]

100. Nigro, E.; Colavita, I.; Sarnataro, D.; Scudiero, O.; Zambrano, G.; Granata, V.; Daniele, A.; Carotenuto, A.; Galdiero, S.; Folliero, V.; et al. An Ancestral Host Defence Peptide within Human $\beta$-Defensin 3 Recapitulates the Antibacterial and Antiviral Activity of the Full-Length Molecule. Sci. Rep. 2015, 5, 18450. [CrossRef]

101. Ganz, T. Antimicrobial Polypeptides. J. Leukoc. Biol. 2004, 75, 34-38. [CrossRef]

102. Ganz, T. Defensins: Antimicrobial Peptides of Innate Immunity. Nat. Rev. Immunol. 2003, 3, 710-720. [CrossRef]

103. Grubman, A.; Kaparakis, M.; Viala, J.; Allison, C.; Badea, L.; Karrar, A.; Boneca, I.G.; Le Bourhis, L.; Reeve, S.; Smith, I.A.; et al. The Innate Immune Molecule, NOD1, Regulates Direct Killing of Helicobacter pylori by Antimicrobial Peptides. Cell Microbiol. 2010, 12, 626-639. [CrossRef] [PubMed]

104. Hamanaka, Y.; Nakashima, M.; Wada, A.; Ito, M.; Kurazono, H.; Hojo, H.; Nakahara, Y.; Kohno, S.; Hirayama, T.; Sekine, I. Expression of Human Beta-Defensin 2 (HBD-2) in Helicobacter pylori Induced Gastritis: Antibacterial Effect of HBD-2 against Helicobacter pylori. Gut 2001, 49, 481-487. [CrossRef] [PubMed]

105. Schlee, M.; Wehkamp, J.; Altenhoefer, A.; Oelschlaeger, T.A.; Stange, E.F.; Fellermann, K. Induction of Human $\beta$-Defensin 2 by the Probiotic Escherichia Coli Nissle 1917 Is Mediated through Flagellin. Infect. Immun. 2007, 75, 2399-2407. [CrossRef]

106. Dolara, P.; Luceri, C.; De Filippo, C.; Femia, A.P.; Giovannelli, L.; Caderni, G.; Cecchini, C.; Silvi, S.; Orpianesi, C.; Cresci, A. Red Wine Polyphenols Influence Carcinogenesis, Intestinal Microflora, Oxidative Damage and Gene Expression Profiles of Colonic Mucosa in F344 Rats. Mutat. Res. 2005, 591, 237-246. [CrossRef]

107. Yang, D.; Chertov, O.; Oppenheim, J.J. Participation of Mammalian Defensins and Cathelicidins in Anti-Microbial Immunity: Receptors and Activities of Human Defensins and Cathelicidin (LL-37). J. Leukoc. Biol. 2001, 69, 691-697. [PubMed] 